\title{
Özel Eğitim Öğretmenlerinin Problem Davranışlara Müdahalede İşbirliğinin Önemine ve Uygulanmasına Yönelik Görüşleri
}

\author{
DOI: $10.26466 /$ opus.727238 \\ * \\ Burhanettin Karakoç* - Zehra Atbaş1 ** \\ * Doktora öğrencisi, Milli Eğitim Bakanlığı, Sivas, Türkiye \\ E-Posta: burhankarakoc2958@gmail.com ORCID: 0000-0001-8213-7809 \\ ** Dr. Necmettin Erbakan Üniversitesi, Özel eğitim Anabilim Dalı, Konya, Türkiye \\ E-Posta: zehrasutcu@gmail.com \\ ORCID: $\underline{0000-0002-2758-1277}$
}

Öz

Bu çalışma özel eğitim okullarında yaşanan problem davranışlara yönelik müdahalede işbirliğinin önemini belirlemek amacıyla yapılmıştır. Araştırmada nitel araştırma yöntemi kullanılmış ve yarı yapılandırılmış görüşme formu ile veriler toplanmıştır. Veriler betimsel analiz tekniği kullanılarak analiz edilmiştir. Araştırmanın çalışma grubunu Sivas ilinde görev yapan 15 özel eğitim öğretmeni oluşturmaktadır. Öğretmenlerle yüz yüze görüşmeler gerçekleştirilerek veriler toplanmıştır. Elde edilen veriler kodlanarak gruplar halinde sunulmuştur. Araştırma sonucunda öğretmenlerin tamamı okul içerisinde birçok problem davranışlarla karşılaştıklarını belirtmişler, en çok karşılaştıkları problem davranışlar ise öğrencilerin kendilerine zarar vermeleri, arkadaşlarna zarar vermeleri, sürekli olarak gezinme, bağırmaları, öfke nöbeti geçirme ıslak mendil ve buldukları yabancı materyalleri yemeleri, yemek yeme bozukluğu (yemekleri dökme, tabakları firlatma), ve etkinlik alanlarına tuvaletlerini yapmalar gibi problem davranışlarla karşılaştıkların belirtmişlerdir. Öğgretmenlerin çoğunluğu aileler ve özel eğitim öğretmenleri ile işbirliğini yaptıklarmn, daha sonra ise okul idaresi, rehberlik servisi ve rehabilitasyon merkezi ile işbirliği yaptıkların belirtmişlerdir. Az sayıdaki katılımoı ise sınıftaki diğer öğretmen arkadaşı ve branş öğretmenleri ile iletişim kurdukların belirtmişlerdir. Araştırmaya katılan öğretmenlerin tamamı işbirliğinin kesinlikle önemli olduğunu ifade etmişler. Özel eğitim öğretmenleri, kendilerini daha iyi ifade ettikleri için genellikle öğrencilerin anneleri ile işbirliği yaptıklarını belirtmişlerdir. Çalışmamıza katılan öğretmenler bu değgişkenlerin ailelerle işbirliğini etkilediğini savunmuşlardır.

Anahtar Kelimeler: Özel eğitim, özel eğitim öğretmeni, problem davranış, işbirliği 


\title{
The Importance of Private Education Teachers For The Importance and Implementation of Cooperation in The Problem Behavior Intervention
}

\begin{abstract}
This study was conducted to determine the importance of cooperation in the intervention of problem behaviors experienced in special education schools. Qualitative research method was used in the study and data were collected with a semi-structured interview form. The data were analyzed using the descriptive analysis technique. The study group of the research consists of 15 special education teachers working in Sivas. The data were collected through face-to-face interviews with the teachers. The obtained data were coded and presented in groups. As a result of the research, all of the teachers stated that they encountered many problem behaviors in school, the most common problem behaviors are students harm themselves, hurting their friends, constantly walking around, yelling, having tantrums, eating wet wipes and foreign materials they find, eating disorder (pouring food. They stated that they faced problem behaviors such as throwing plates, and defecating in activity areas. Most of the teachers stated that they cooperated with parents and special education teachers, and then they cooperated with the school administration, guidance service and rehabilitation center. A small number of participants stated that they communicated with other teacher friends and branch teachers in the classroom. All of the teachers participating in the research stated that collaboration is absolutely important. Special education teachers stated that students generally cooperate with their mothers because they express themselves better. Teachers who participated in our study argued that these variables affect cooperation with families.
\end{abstract}

Keywords: Special education, special education teacher, problem behavior, cooperation 


\section{Giriş}

Eğitimin temel amacı tüm bireylerin topluma sağlıklı ve verimli bir şekilde uyumunu sağlamak, okul içerisinde meydana gelen istenmeyen davranışların ortadan kaldırılarak öğrencilerin yeteneklerini keşfetmek, etkili ve verimli bireyler yetiştirmektir. Okulda kazanılan bilgi, beceri, alışkanlıklar ve değerler çocuğun sadece öğrenim yaşantısını değil kendine, topluma, kendi dışındaki dünyaya karşı iletişim ve yaşam becerilerini de önemli ölçüde etkilemektedir (Sadık, 2000; Senemoğlu, 1992). Ancak okul ortamının ve tüm sürecin uyumunu ve düzenini bozan bazı etkenler bulunmaktadır. Bu etkenler arasında problem davranışlar önemli bir paya sahiptir. Problem davranışlar, alanyazında "sergilenen davranışın şiddeti, sıklığı ve süresi göz önünde bulundurulduğunda kültürel olarak anormal sayılabilecek ve kişinin kendisinin veya başkalarının fiziksel güvenliğini ciddi biçimde riske edebilecek davranışlar" olarak belirtilmektedir (Emerson, 2001). Okullarda pek çok problem davranış görülebilmektdir. Bu problem davranışlar öğrencilerin öğrenmelerinin önüne geçerken sınıf ortamına, öğretmenlere ve diğer öğrencilere de olumsuz etkileri olmaktadır (Özbey, 2010). Belli düzeyde problem davranış sergileyen öğrenciler bu durumun oluşturduğu bir sonuç olarak eğitim ve öğretim olanaklarından yeterince yararlanamamakta ve akademik ve diğer alanlarda başarısız olmaktadır (Chandler ve Dahlquist, 2002; Kırcaalı-İftar ve Tekin İftar, 2004; Putman, Luiselli, Handler ve Jefferson, 2003). Dolayısıyla, öğrencilerin okuldaki performanslarını arttırmak ve okul ortamların herkes için daha uygun hale getirebilmek amacıyla problem davranışlar azaltılmalı ya da ortadan kaldırılmalıdır (Chandler ve Dahlquist, 2002; Erbaş, 2008).

Problem davranışlar okul ortamlarında sadece tek mekân ve belli kişilerin varlığında ortaya çıkan, durumlara ve gerçekleştikleri yer, zaman ve ortamda bulunan kişilerin özelliklerine bağlı olarak da şekillenebilmektedirler. Bu nedenle davranış problemlerinin ele alınması ve uygun müdahalenin planlanıp uygulanabilmesinde bütüncül yaklaşımlar ön plan çkmaktadır (Sugai ve Horner, 2002). Okul içerisinde gerçekleşen çalışmalarda o okulda çalışan tüm personelin bunun parçası olmasına dikkat edilmesi konuyu ortaya koyma bakımından daha kapsayıc bir duruma fırsat sağlayacaktır. Problem davranışlara yönelik alınacak önlemlerin belirlenebilmesi ve gerekli verinin oluşması için ortamın çalışanlarıyla birlikte kapsamlı olarak tanım- 
lanması gerekmektedir (Alberto ve Troutman, 2012). Bu yaklaşım çerçevesinde öğrenciyle doğrudan etkileşimde bulunan paydaşlardan bilgi almak varsayımların yerine mevcut durumun verilerle ortaya konulmasını sağlayacaktır. Problem davranışların yoğun olduğu okul ortamı yerine olumlu okul ve sınıf ortamının oluşturulabilmesi için yönetici, sınıf öğretmeni ve diğer öğretmenlerin işbirliği içinde olması gerekmektedir (Özgan ve Aydın, 2010).

İşbirliği, ortak bir hedef doğrultusunda gönüllü olarak ortak karar alma sürecine katılan en az iki eşit taraf arasındaki doğrudan etkileşim biçimidir (Cook ve Friend, 1991). İşbirliği, profesyonellerin ve ailelerin öğrencilerin ihtiyaçlarını karşılamak amacıyla karşılıklı çabalarını kapsamakta ve profesyoneller arasında farklı ancak eşit konuma sahip olma anlamına gelmektedir (Coben, Thomas, Sattler ve Morsink, 1997). Öğretmenlerin akademik yetenekleri ve nitelikleri öğrenci başarısıyla ilişkidir. Farklı öğrenme güçlüğüne sahip öğrencilerin akademik olarak ilerlemelerinde öğretmen ve aileler birlikte hareket ettiğinde öğrencilerin başarısı artmakta (Goddard, Goddard ve Tschannen-Moran, 2007; Goddard, Miller, Larson ve Goddard, 2010), aile öğretmen iletişimi sonucunda olumsuz davranışlar azalmakta (Thousand, Nevin, Mcneil ve Listen, 2006) ve öğrencilerin sosyal becerileri gelişmektedir (Walther-Thomas, 1997).

İşbirliği öğretmenleri birbirlerini desteklemeleri için teşvik etmenin bir yoludur. Bununla birlikte, öğretmenler arasındaki işbirliği özel gereksinimli öğrencilerin ihtiyaçlarını karşılamaya yardımcı olmak için gerekli olan kritik bileşen olarak görülmektedir (Friend ve Cook, 2012). Ancak, öğretmenlerin sahip oldukları inançlar ve değer yargıları işbirliği sürecini etkilemektedir (Bhandari, 2013). Öğretmenler için işbirliğinin öğrenme ve öğretmeyi geliştirme (Goddard ve Heron, 2001), etkililiği arttırma (Shachar ve Shmuelevitz, 1997), öğretime karşı olumlu tutum geliştirme, (Yeager, Rennells ve Riley, 1997) ve yüksek güven düzeyine sahip olma (Tschannen-Moran, 2001) gibi olumlu sonuçları olduğu belirtilmektedir. Problem davranışları en aza indirmede veya ortadan kaldırılmasında öğretmenin yöneticilerle, aile ve rehberlik servisi ile işbirliğinin çok önemlidir (Ceylan ve Yıkmış, 2017). Okul yönetimi- öğretmenler ve ailenin iletişim ve işbirliği içinde olması sadece öğrencinin okul başarısına değil aynı zamanda öğrencinin sosyalleşmesine, olumlu benlik gelişimine de etki eder. Aile ile iletişimin güçlü ve dinamik olması her iki tarafında öğrencilere anlayışla yaklaşmaları, öğrencilerin ilgi 
ve yeteneklerinin dikkate alınması ailelerin okul etkinliklerine ve özel günlere aktif katılmaları hem öğrencinin motivasyonunu arttırır hem de problem davranışların en aza indirilmesinde olumlu etkiye sahip olduğu düşünülmektedir.

Okul içerisinde problem davranışların azalması ve ortadan kaldırılmasında okul yönetimi, öğretmen ve ailelerin ortak bir çaba içerisinde olmaları yaşanan sorunlara anlayış ve çözüm odaklı yaklaşmaları öğrencilerin ilgi ve ihtiyaçlarına göre hareket ederek öğrencilerin problem davranışlarını en aza indirmede etkilidir (Aslanargun, 2007). Bunun yanında Çelenk (2003)'in belirttiği gibi okul ile ortak bir program üzerinde görüş birliği olan ve bu ortak anlayış içerisinde çocuğuna sürekli destek sağlayan ailelerin çocuklarının okul başarısı ve bu başarıya bağlı olarak problem davranışların azaldığı hatta ortadan kalktı̆̆ı sonucuna ulaşılmıştır. Eğitim- öğretimde başarıya ulaşmak isteyen ve problem davranışları minimum seviyeye indirmek isteyen okul yönetimi, uygulanacak olan programlarda öğretmen kadar aileleri de katılımcı hale getirebilmek için, anne- baba ve öğretmen iletişimine önem vermelidir (Akbaşlı ve Kavak, 2008).

Okulun ve öğretmenlerin aile ile iletişimi çocuklarda ve gençlerde akademik başarıyı ve okula olan ilgiyi arttırırken öğrencilerde olumsuz davranışların azalmasında etkili olabilmektedir. Öğrencilerin çalışma isteklerinin artması ile öğrencilerde iç denetim mekanizması oluşur ve iç denetim mekanizmasının artması sonucunda öğrencilerin kendi öz benliklerinin olumlu yönde oluşması sağlanmış olur (Ceylan ve Akar, 2010).

Özel eğitimde işbirliği ve problem davranışların çözümünde yurt dışında genellikle sınıf öğretmeni ve özel eğitim öğretmeni arasındaki işbirliğinin önemine, işbirliğinin öğrenci başarısını nasıl etkilediğine ve başarının problem davranışları nasıl ortadan kaldırdığına, özel eğitimde işbirliğinin nasıl gerçekleştiğine odaklandığ1 görülmüştür (Mchenry, 2009; Radic-Šestic vd., 2013; Roustaee, Pourrajab, Kasmaienezhadfard ve Taleblo, 2015; Shachar ve Shmuelevıtz, 1997).Yurt içinde ise özel eğitim okullarında yaşanan problem davranışların çözümünde daha çok öğretmen aile iletişiminin ön plana çıtığı görülmüştür. Gökçe' e (2000) göre okul ve aile iletişiminin güçlendirilebilmesi için, ailelerin okuldaki çalışmalara katılması, çocuk gelişimi konusunda bilinçlendirilmesi, çocuğun sorunlarıyla yakından ilgilenmeleri, okullarda uygun bir öğrenme ortamının oluşmasında ve problem davranışların ortadan kaldırılmasında etkilidir. 
Okul yönetimi bu iletişimin güçlendirilmesi amacıyla gerekli ortamı ve desteği sağlamalıdır. Özel eğitim öğrencilerinde ortaya çıan problem davranışların ortadan kaldırılması normal gelişim gösteren öğrencilere göre daha zor ve daha uzun bir süreci kapsamaktadır (Özgan ve Aydın, 2010). İlgili alanyazını incelendiğinde özel eğitimde işbirliğinin öneminin vurgulandığı (Batu ve Kırcaali-İftar, 2006; Sucuoğlu ve Kargın, 2014) ancak yapılan çalışmalarda doğrudan işbirliğine yönelik olmaktan ziyade, aile öğretmen işbirliğine vurgu yapıldığı görülmektedir (Sivrikaya ve Yıkmış, 2017). Özsoy (2019) yaptığı araştırmasında özel eğitim öğretmenlerinin öncelikle diğer öğretmelerle işbirliği yapmayı tercih ettikleri ve ailelerle işbirliği düzeylerinin en az düzeyde olduğu ile genel olarak özel eğitim öğretmenlerinin okul müdürleri, diğer öğretmenler ve aileler ile işbirliği içinde olduğu sonucuna ulaşmıştır.

Problem davranışlar ve etkileri göz önüne alındığında bütüncül bir yaklaşımla sağaltımlarının önemi üzerinde durulmaktadır. Fakat bütüncül bakış açısı içerisinde problem davranışların sağaltımında işbirliğinin önemine yönelik betimsel ya da deneysel bir çalışmaya rastlanamamıştır. Bu nedenle çalışmanın amacı; özel eğitim öğretmenlerinin problem davranışlara müdahalede işbirliğinin önemine ve uygulanmasına yönelik görüşlerini belirlemektir.

$\mathrm{Bu}$ amaç doğrultusunda öğretmen görüşlerine göre aşağıdaki sorulara cevap aranmıştır;

1. Özel eğitim öğretmenlerinin karşılaştıkları problem türleri nelerdir?

2. Özel eğitim öğretmenlerinin işbirliğinin önemine yönelik görüşleri nelerdir?

3. Özel eğitim öğretmenleri problem davranışlara müdahalede kimlerle ne düzeyde işbirliğine girmektedir?

4. Özel eğitim öğretmenleri problem davranışlara müdahalede aileyle işbirliğine ne düzeyde girmektedir? Bu işbirliğini etkileyen faktörler nelerdir?

\section{Yöntem}

Bu çalışmada nitel araştırma yaklaşımı kullanılmıştır. Özel eğitim öğretmenlerinin belirlenen amaç doğrultusunda düşünce ve yaşadıklarının tespi- 
tinin ortaya konulmasında en uygun yaklaşım olacağı düşünüldüğü için bu yaklaşım esas alınmıştır. Nitel araştırmalar, araştırma yapılan ya da yapılması planlanan kişilerin sahip oldukları deneyimlerden doğan anlamların sistematik olarak incelenebilmesinden tercih edilen bir yaklaşımdır (Ekiz, 2013). Nitel araştırma yöntemi gözlem, görüşme ve doküman analizi gibi nitel veri toplama araçlarının birlikte kullanıldığı, olayların ve algıların doğal ortamda ortaya konmasına yönelik nitel bir sürecin izlendiği araştırmalardır (Yıldırım ve Şimşek, 2000). Bu çalışmada derinlemesine ve ayrıntılı bilgi elde edebilmek için ise görüşme tekniği kullanılmıştır.

\section{Çalışma Grubu}

Araştırmada Sivas il merkezinde özel eğitim okullarında görev yapan 15 özel eğitim öğretmeni araştırmanın çalışma grubunu oluşturmuştur. Aşağ1daki tablo da çalışma grubunun demografik bilgilerine yer verilmiştir.

Tablo 1.Öğretmenlerin demografik bilgileri

\begin{tabular}{llll}
\hline Değişkenler $\mathbf{n = 1 5}$ & & $f$ & $\mathbf{\%}$ \\
\hline Cinsiyet & Kadın & 7 & 46,7 \\
& Erkek & 8 & 53,3 \\
\hline Branş & Özel eğitim & 15 & 100 \\
& Diğer branş & & \\
\hline Kıdem yılı & $0-3$ yıl & 7 & 46,6 \\
& $3-6$ yıl & 3 & 20 \\
& 6-10 yıl & 3 & 20 \\
& 10 ve üzeri & 2 & 13,4 \\
\hline Öğrenim durumu & Lisans (Özel eğitim) & 15 & 100 \\
& Lisans üstü & & \\
\hline
\end{tabular}

Çalışma grubunda yer alan öğretmenlerin yedisi kadın öğretmen sekizi ise erkek öğretmendir. Öğretmenlerin yedisi 0-3 yıllık mesleki deneyime, üçü 3-6 yıllık mesleki deneyime, yine üç öğretmen 6-10 yıllık deneyime, iki öğretmen ise 10 yıl ve üzeri mesleki deneyime sahiptir. Çalışmaya katılan öğretmenlerin tamamı lisans düzeyinde eğitim almıştır.

\section{Veri Toplama Aracı ve Geliştirilmesi}

Bu araştırmada özel eğitim öğretmenlerinin problem davranışlara müdahalede işbirliğinin önemini ve uygulamasına yönelik görüşleri belirleyebilmek 
için görüşme yöntemi tercih edilmiş bunun için yarı yapılandırılmış görüşme formu oluşturulmuştur Yarı yapılandırılmış görüşme formunun hazırlanış sürecinde öncelikle ilgili alan yazın taraması yapılarak on maddelik ilk form oluşturulmuştur. Daha sonraki aşamada ise form ile ilgili özel eğitim bölümünde öğretim üyesi olan ve bu konularla ilgili çalışmaları olan bir uzmandan görüş alınmış ve çalışmanın katılımc grubuna benzer özellikler taşıyan bir özel eğitim öğretmeni ile pilot çalışma yapılmış ve gerekli görülen düzenlemeler yapıldıktan sonra görüşme formuna son hali verilmiştir. Çalışmada veriler yarı yapılandırılmış görüşme formu aracilığı ile yüz yüze görüşerek toplanmıştır.

\section{Veri Toplama Süreci}

Araştırmanın örneklem grubunu, Sivas İli'nde Milli Eğitim Bakanlığı'na bağlı özel eğitim öğretmenleri oluşturduğu için İl Milli Eğitim Müdürlüğünden öncelikli olarak araştırma izni alınmıştır. İl Milli Eğitim Müdürlüğü'nün ilgili araştırmanın yürütülmesini uygun görmesi sonucunda araştırma izin dilekçesinin ek kısmında yer alan okullara izin yazısı ile gidilmiştir. Bu okullarda yer alan özel eğitim öğretmenlerine ilgili çalışmanın detayları sunulmuş ve gönüllü olan öğretmenlerle 2019 yılı güz döneminde görüşmeler gerçekleşmiştir.

Görüşmeler esnasında geliştirilen görüşme protokolü uygulanmıştır. Bu protokol, görüşmeyi gerçekleştiren araştırmacının tüm katılımclara soruları aynı biçimde sorması, sorulara verilen yanıtları genişletme, tekrar ettirme ve özetleme gibi görüşmeci tekniklerinin etkin biçimde kullanılmasına dair maddeler içermektedir. Görüşmeler, ses kaydı için izin alındıktan sonra ses kayıt cihazı ile yürütülmüş daha sonra ses kayıtlarının dökümü yapılmıştır.

\section{Verilerin Analizi}

Araştırma sürecinde görüşmeler yapıldıktan sonra katılımcıların verdikleri cevaplar bilgisayar ortamına aktarılmıştır. Elde edilen görüşler kodlama yapılmadan önce iki araştırmacı tarafından görüşme dökümü tek tek okunmuştur. Görüşme verilerinin analizinde betimsel analiz tekniği kullanılmıştır. Betimsel analiz yönteminde toplanan veriler üzerinde hiçbir işlem yapılmadan okuyucuya olduğu gibi sunulması savunulur. Bu yöntemle 
araştırmacı tarafından elde edilen bulguların yorumlanıp farklı bir biçimde göstermesi engellenir. Elde edilen verilerin açık ilk haliyle sunulması, tarafsızlığın sağlanması açısından önemlidir. (Sönmez ve Alacapınar, 2011).

Katılımclara (K1, K2, K3, ,'ו,', K15 ) kısaltmalar kullanılarak kod verilmiştir.

\section{Bulgular}

Araştırmada elde edilen veriler dört başlık altında toplanmıştır Elde edilen veriler analiz edilerek katılımcların yorumlarıyla desteklenerek raporlaştırilmıştır.

Tablo 2. Özel eğitim öğretmenlerinin karşılaştıkları problem davranış türleri

\begin{tabular}{|c|c|c|}
\hline & Katılımcilar & $\mathbf{f}$ \\
\hline Bekleme davranışının oluşmaması & K1 & 1 \\
\hline El çırpma, burun karıştırma & K1, K11, K14 & 3 \\
\hline Bağırma, sürekli konuşma, tekrarlanan takıntılar & $K 1, K 3, K 4, K 8, K 10, K 14$ & 6 \\
\hline Islak mendil, ip, materyal yeme & $K 1, K 6, K 8, K 14$ & 3 \\
\hline Tükürme veya herhangi bir yeri yalama & $K 2, K 3, K 5, K 6, K 11$ & 5 \\
\hline Arkadaşlarına zarar verme & $K 2, K 4, K 8, K 10, K 11, K 12, K 13, K 14, K 15$ & 9 \\
\hline Kendine zarar verme, isırma & $\begin{array}{l}K 2, K 3, K 5, K 6, K 7 \\
K 8, K 9, K 11, K 14, K 15\end{array}$ & 10 \\
\hline Etkinlik tamamlayamama & K2 & 1 \\
\hline Gezinme & $K 2, K 4, K 8, K 12, K 13, K 14$ & 6 \\
\hline Yeme bozukluğu (Yemekleri dökme-dağıtma) & K5, K7 & 2 \\
\hline Teneffüs alanlarına tuvaletini yapma & K6 & 1 \\
\hline Öfke nöbeti & $K 7, K 14, K 15$ & 3 \\
\hline
\end{tabular}

Görüşme yapılan özel eğitim öğretmenlerinin tamamı sınıflarında birçok problem davranışların yaşandığını belirtmişlerdir. Sınıf içinde karşılaşılan problem davranışlar içerisinde en çok kendine zarar verme ve ısırma davranışın 10 öğretmen ( \%66) belirtmiştir. Araştırmaya katılan öğretmenlerden dokuzu ( \%60) arkadaşına zarar verme davranışının yaşandığını belirtmişlerdir. Katılımcıların altısı ise (\%40) gezinme, bağırma, sürekli konuşma ve takıntılı davranışlar gibi problem davranışların yaşandığını rapor etmişlerdir. Beş katılımc ise (\%33) tükürme veya herhangi bir yeri yalama problem davranışının yaşandığını belirtmiştir. El çırpma, burun karıştırma problem davranışını üç (\%20) katılımcı, sslak mendil, ip, materyal yeme gibi davranışlarla karşılaştıklarını bunun yanında yine üç (\%20) katılımcı öfke nöbeti geçirme davranışlarının yaşandığını belirtmiştir. İki katılımcı ise 
\%13'ü öğrencilerde yeme bozukluğu (yemekleri dökme-dağıtma) olduğu belirtmiş ve birer (\%6) katılımcı ise teneffüs alanlarına tuvaletini yapma, etkinliği tamamlayamama ve bekleme davranışının olmaması gibi problem davranışlarla karşılaştıklarını ifade etmişlerdir.

Aşağıda kesitlere yer verilmiştir.

- 'Problem davranışlarla sık sık karşılaşıyorum. Ayakkabılarını çıkarma, yerden taş vb alıp kafasına sürme, sinir krizi geçirip kulağın kanatma, elini ısırma gibi problem davranışlar görülmektedir. Ayrıca ek olarak yemekhanede yemeklere saldirma hızl bir şekilde yemedir $(K, 7)$.

- 'Her öğrencinin en az 1 tane problem davranışı vardır. Problem davranışlarm sıklğ̆ı her öğrenciye göre değisşiyor. Ama genel olarak bir ders saatinde iki defa problem davranışla karşılaşıyoruz. Yerine oturmama, bağırma, arkadaşına vurma, önündeki nesneleri firlatma, tırnak yeme, ellerini ısırma gibi davranışlarla sık sık karşılaşıyoruz $(K, 8)$.

- 'Sinıfta gezinme problem davranışı ile çok sık karşılaşıyorum. Simıftan çıkma, pencereye tırmanma gibi problem davranışlara çok nadir rastlıyorum. Saç çekme, asılma gibi problem davranışlara çok nadir rastlyorum(K,12).

- Her gün sik sık karşılaşıyoruz. Tükürme, vurma, ayakta gezinme, kendine zarar verme (El ısırması), etkinlikten kaçma gibi davranışlarla karşılaşıyo$\operatorname{ruz}(K, 2)$.

- 'Sürekli karşılaşıyoruz. Otizmli bireyler ile çalışıyoruz. Özellikle tekrarlayan takıntılar bizleri çok yoruyor. Bekleme davranışlarmmn oluşmaması, el çırpma, tekrarlayan sesler, iplik yeme davranışı, ıslak mendil boya yeme davranışları $(K, 1)$.

- 'Haftada bir defa karşılaşmak zorunda kalıyoruz. Sinir krizi geçirme, üzerini yırtma, başkalarına saldırma davranışıla karşı karşıya kalıyoruz $(K, 15)$.

- 'Çoğunlukla kendine bazen de başkasina saldırma davranışları. Herhangi bir yüzeyi yalama, yerde bulunan cisimleri yeme, bazen teneffüs alanlarma tuvaletini yapma $(K, 6)$. 
Tablo. 3 Problem davranışlara müdahalede işbirliği kurma

\begin{tabular}{lll}
\hline & Katılımcllar & $\mathbf{f}$ \\
\hline Okul idaresi & $K 5, K 6, K 7$ & 3 \\
Aile & $K 2, K 3, K 4, K 7, K 9$, & 10 \\
& $K 10, K 11, K 12, K 13, K 14$ & \\
Özel eğitim öğretmenleri ile & $K 5, K 6, K 9, K 11, K 12, K 14, K 15$ & 7 \\
Rehabilitasyon merkezi & $K 5, K 13, K 14$ & 3 \\
Sinıftaki diğer öğretmenle & $K 1, K 4$ & 2 \\
Branş öğretmenleri ile & $K 4, K 8$ & 2 \\
Rehberlik servisi & $K 5, K 13, K 14$ & 3 \\
Personel & $K 5$ & 1 \\
\hline
\end{tabular}

Araştırmaya katılan özel eğitim öğretmenlerinin10’u (\%66) ailelerle işbirliği kurmayı kendilerinin başlattıkları ve problem davranışların söndürülmesinde aile ile işbirliğinin çok önemli olduğunu belirtmiştir. Ailelerin problem davranış hakkında bilgilendirilmeleri hem problem davranışın ortadan kalkmasında hem de kontrol altına alınmasında etkili olduğunu rapor etmişlerdir. Katılımcllardan yedisi (\%46) özel eğitim öğretmenleri ile işbirliği yaptıklarını belirtmiştir. Kendi branşları ile iş birliği yapmaları ortaya çıkan ve mevcut problem davranışların ortadan kalkmasında nasıl bir yol izledikleri hakkında paylaşımlar yapmaları problem davranışların ortadan kalkmasında etkili olduğunu rapor etmiş̧lerdir. Katılımcıların iş birliği yaptıkları en çok üçüncü sırada ise her birini üç (\%15) katılımcının belirttiği okul idaresi, rehberlik servisi ve iyileştirme merkezi ile işbirliği içinde olduklarını, yine katılımcılardan ikisi (\%13) sınıftaki diğer öğretmenle işbirliği yaptıklarını, diğer iki katılımcı ise branş öğretmenleriyle işbirliği yaptıkları$\mathrm{n}$ belirtmiştir. Bir katılımcı ise personelle işbirliği yaptığını belirtmiştir. Aşağıda kesitlere yer verilmiştir.

- ‘Okulda öğretmen arkadaşlarımızı çocuğun ilgili problem davranış ile ilgili bilgilendirip uygun tepkide bulunmalarmı söylüyoruz. Problem davranışı değiştirmede aile öğretmen işbirliği de çok önemli bir yere sahiptir. Öğretmen aileyi problem davranışla ilgili bilgilendirip öğrenci problem davranışı gösterdiğinde uygun tepkiyi vermeleri konusunda bilgilendiriyorum $(K, 11)$ '.

- 'Öncelikle sorunun kaynağın bulmak için aile ile iletişim kuruyorum. Daha sonra özel eğitim öğretmeni olan arkadaşımla iletişime geçiyorum. Ve fikir alışverişte bulunuyorum $(K, 12)^{\prime}$. 
- ‘Okul müdürü, müdür yardımcllar, personel, rehber öğretmen ve diğer meslektaşlarımız ile yoğun etkileşim işbirliği var $(K, 5)$ '.

- 'Genellikle derse giren öğretmenlerle işbirliği kurularak öğrencinin bu davranışı neden yaptı̆̆ına dair konuşuluyor. Bu konuşmaya göre uygulamalı davranış analizi kullanarak öğrencinin problem davranışını söndürmeye çalışıyo$\operatorname{ruz}(K, 8)^{\prime}$.

Tablo 4. Problem davranışlara müdahalede işbirliğinin önemine ilişkin görüşler

\begin{tabular}{lll}
\hline & Katılımcllar & $\mathbf{f}$ \\
\hline İş birliği kesinlikle çok önemli & $\mathrm{K} 1, K 2, K 3, K 4, K 5, K 6, K 7, K 8$ & 15 \\
& $K 9, K 10, K 11, K 12, K 13, K 14, K 15$ & \\
İstenilen davranışı kalııı hale getirmesi & $K 1, K 2, K 5, K 7, K 9, K 14, K 15$ & 7 \\
Tutarlı olmalı & $K 3, K 4, K 10, K 12, K 13$ & 5 \\
Genellemeye hizmet etmesi & $K 3, K 6, K 7, K 8, K 11$ & 5 \\
Uygulamayı kolaylaştırması & $K 2, K 8$ & 2 \\
\hline
\end{tabular}

Araştırmaya katılan özel eğitim öğretmenlerinin tamamı (\%100) işbirliğinin önemli olduğunu ve işbirliğinin özellikle özel eğitimde çok önemli olduğunu belirtmişlerdir. Katılımcıların yedisi (\%46) işbirliğinin istenilen davranışı kalıı hale getirdiğini belirtmiştir. İşbirliği ile kazandırılmak istenilen davranışların kalıcı hale geldiği süreklilik kazandığını belirtmişlerdir. Katılımcların beşi $(\% 33,3)$ işbirliğinin tutarlı olmasını savunmuşlardır. İş birliğinde tutarlılık problem davranışın ortadan kaldırılmasında önemine vurgu yapmıştır. Yine katılımcıların beşi /\%33,3) işbirliğinin genellemeye hizmet etmesini belirtmiştir. Problem davranışın ortadan kalkması veya azalmasında uygulanan yöntemlerin her duruma genellemesi önem taşımaktadır. Üç katılımcı $(\% 13,3)$ iş birliğinin uygulamayı kolaylaştırdığını belirtmiştir. Aşağıda kesitlere yer verilmiştir.

- 'Tek başına öğretmen hiçbir şeyde etkili değildir. İlk önce aile ile işbirliği kurmak çok önemli. Müdahale durumunda tutarl olmall, ve evde de bu tutarhliğm devam ettirilmesi să̆lanmalıdır $(K, 3)$.

- 'İşbirliği olmadan müdahale tek taraflı kalmadığı için işe yaramıyor. Ya da çocuk müdahale yapılmayan yerde bu davranışı yine yapıyor. Bu yüzden müdahalede işbirliği önemli devamlılık kazanması ve davranışın değiş̧mesi açısından. Aynı şekilde idareyle işbirliği de önemli idare öğretmenin ihtiyaçlarını göze alı okulda uyarlama yapmalı ve önlemler almalıdır $(K, 7)$.

- 'Davranışın söndürülmesi aşamasında büyük bir öneme sahip olduğunu düşünüyorum. Davranışı söndürme aşamasında her öğretmenin ayrı kararlılıkla 
kullanulan yöntemi her duruma genellemesi noktasında çok önemli olduğunu düşünüyorum $(K, 8)$.

- 'Problem davranışı değiştirmek istiyorsak mutlaka özellikle öğrencinin vakit geçirdiği kişileri, öğretmenleri ve aileyi bilgilendirmeliyiz. Problem davranışla mücadele de işbirliği hayati öneme sahiptir. Çocuğun uygun davranışı genellemesini să̆lamalıyız. Bu açıdan davranış konusunda işbirliği içinde olmak çok önemlidir. (K,11).'

Tablo 5. Aile ile işbirliği ve etkileyen faktörler

\begin{tabular}{lll}
\hline & Katılımcllar & $\mathbf{f}$ \\
\hline Gelir düzeyi etkili & $K 2, K 4, K 5, K 7, K 8, K 12, K 15$ & 7 \\
Eğitim seviyesi etkili & $K 2, K 3, K 4, K 5, K 7, K 8, K 11, K 12, K 15$ & 9 \\
Eğitim seviyesi etkili değil & $K 3$ & 1 \\
Cinsiyet etkili & $K 2, K 3, K 4, K 5, K 8, K 12, K 15$ & 7 \\
Cinsiyetin önemi yok & $K 7$ & 1 \\
Bu değişkenlerin önemi yok & $K 1, K 6, K 9, K 10, K 13, K 14$ & 6 \\
\hline
\end{tabular}

Araştırmaya katılan öğretmenlerin 7'si (\%60) gelir düzeyinin ailelerle işbirliğini etkilediğini belirtmiştir. Gelir düzeyi arttıkça insanların bakış açılarının değiştiğgini ifade etmişlerdir; yine katılımcıların dokuzu (\%60) eğitim seviyesinin ailelerle iletişimi etkilediğini belirtmişlerdir. Eğitim seviyesinin aileler arasında iletişimi kolaylaştırdığını, insanların birbirlerini daha kolay anladıklarını savunmuşlardır. Bir katılımcı $(\% 6,6)$ eğitim seviyesinin etkili olmadığını belirtmiştir. Katılımcılardan altısı (\%40) ailelerle iletişimde cinsiyetin etkili olduğunu, bir katılımcı $(\% 6,6)$ cinsiyetin etkili olmadığını ifade etmiştir. Cinsiyetin etkili olmasında bayanlar erkeklere göre daha anlayışlı bir yaklaşımla durumu ele aldıkları ifade edilmiştir. Araştırmaya katılan altı (\%40) ise bu değişkenlerin öneminin olmadığını ifade etmişlerdir.

- 'Genelde bu durumlarda annelerle işbirliği yapılıyor. Evde çocuğuyla daha çok ilgilenen kişiler genelde anneler olduğu için. Ë̆itim seviyesi yükssek ise gelir düzeyi de diğerine göre yüksek oluyor. Ĕ̆itim seviyesi yüksek olan ailelerde işbirliği kolay çünkü çocuğun problem davranışı olduğunu kabulleniyor. Diğer aileler ise sürekli bir bahane bulma hali içerisinde kalıyor. 'Çocŭ̆un problem davranışına sürekli bahaneler buluyorlar, kabullenmiyorlar(K,12)'.

- 'Gelir düzeyi yüksek ailelerin çocuğun sorunları ile daha fazla ilgilendikleri sık sık gözlemlemekteyiz. Sosyo-kültürel çevre kadınların bir erkekle sık sık iletişim kurması engellendiğinden cinsiyet farklılı̆̆ işbirliğinde etkilidir. Ĕ̆itim seviye- 
si yüksek aileler düşük ailelere göre daha araştırmacı ve daha anlatılanları dinlediklerinden eğitim seviyesi de işbirliğini etkiler $(K, 2)$ '.

- 'Düşünüyorum, ancak gelir düzeyinden ziyade eğitim seviyesi ve cinsiyet kavramları etken olmakta. Eğitim kültür seviyesi yüksek olan aileler genellikle iletişime ve yüzleşmeye daha yatkm oluyorlar ve sorunu reddetmek yerine çözüm arıyorlar. Cinsiyet kavramı ise özellikle yaşadığımı şehrin sosyo-kültürel düzeyi gereği öğrencilerin cinsel eğitimleri, ergenlik dönemlerine ilişkin konularda hemcinsimiz olan ebeveynlerle daha kolay iletişimde bulunuyoruz $(K, 4)$.'

- 'Hayır düşünmüyorum. Eğitimli insanlar biraz daha problemli davranabiliyorlar. Burada ailenin çocuğun iyiliğini düşünmesi ve sorumlu davranmast yeterli. Ĕ̆itimli insanlar kendi yanlış bildiklerini doğru kabul edip işbirliğine gitmeyebiliyorlar $(K, 10)^{\prime}$.

- 'Cinsiyet işbirliğinde etkili değgil. Eğitim seviyesi ise etkili aile ile iletişim açısından. Gelir düzeyi etkili çocuğun eğitimle ilgili ihtiyaçlarm görmek eğitimle ilgili istenileni yapabilmek açısından önemli $(K, 7)^{\prime}$.

\section{Sonuç, Tartışma Ve Öneriler}

Özel eğitim okullarında yaşanan problem davranışlara yönelik müdahalede işbirliğinin önemini belirlemek amacıyla bu çalışmada 15 özel eğitim öğretmeniyle yüz yüze görüşülmüş, yapılan görüşme formları kategorileştirilerek verilerin analizi yapılmıştır. Araştırma sonucunda öğretmenlerin tamamı okul içerisinde birçok problem davranışlarla karşılaştıklarını belirtmişlerdir. En çok karşılaştıkları problem davranışlar öğrencilerin kendilerine zarar vermeleri, arkadaşlarına zarar vermeleri, sürekli olarak gezinme, bağırmaları, öfke nöbeti geçirme ıslak mendil ve buldukları yabancı materyalleri yemeleri, yemek yeme bozukluğu (yemekleri dökme, tabakları fırlatma), ve etkinlik alanlarına tuvaletlerini yapmaları gibi problem davranışlarla karşılaştıklarını belirtmişlerdir. Araştırmanın bu bulgusu, Atcı (2004), Kapucuoğlu-Tolunay (2008), Keskin (2009), Sazak-Pınar ve Güner-Yıldız (2013)'ın yapmış oldukları çalışmalardaki öğrencilerde karşılaşılan problem davranışlar bulguları ile benzerlik göstermektedir. Problem davranışların azaltılması veya minimum düzeye indirmek amacıyla öğrencilere gerekli eğitimler sağlanmalı, bu problemlerin ortadan kalkması amaciyla eğitim süreç boyunca devam ettirilmelidir. En çok karşılaşılan kendilerine ve arkadaşlarına zarar verme davranışı meydana geldiği için en başta öğrencilerin 
birbirlerine saygı duymaları ve değer vermeleri sağlanmaya çalışılmalıdır (Anlıak ve Dinçer, 2005). Okullarda ailelere yönelik problem çözme ve arabuluculuk eğitiminin verilmesi ile çocuklardaki problem davranışların ortadan kaldırılması veya hafifletilmesi gerçekleştirilebilir. Problem davranış sergileyen çocuklara ise problemlerle nasıl başa çıkabilecekleri veya sergiledikleri olumsuz davranışların üstesinden gelme konusunda uygulamalı davranış analizi ile eğitimler verilmelidir. Bu eğitimlerle bireylerin ilişkilerinde yaşanan problemlere farklı çözümler üretebilme becerisinin kazandırılmasına katkı sağlayacağı öngörülmektedir. Öğretmenlerin çoğunluğu ailelerle ve özel eğitim öğretmenleri ile işbirliğini yaptıklarını belirtmişlerdir. Daha sonra ise okul idaresi, rehberlik servisi ve rehabilitasyon merkezi ile işbirliği yaptıklarını belirtmişlerdir. Az sayıdaki katılımcı ise sınıftaki diğer öğretmen arkadaşı ve branş öğretmenleri ile iletişim kurduklarını belirtmişlerdir. Bir katılımcı ise personelle işbirliği yaptığını ifade etmiştir. Özel eğitim sınıflarında öğrencilerin gelişim ve ilerlemelerinde aile ve diğer özel eğitim öğretmenleri ile işbirliği son derece önemlidir. Aileler okulda yapılanları evde devam ettirmeleri açısından hayati öneme sahiptir. Gökçe (2000), Yaptı̆̆ araştırmada öğretmenlerin, ailelerle işbirliğinin güçlendirilebilmesi amacıyla, ailelerin okulla işbirliği yapmaları, aileler çocukların gelişimi konusunda bilinçlendirilmeli, çocuğun sorunlarılya yakından ilgilenmeleri sağlanmalı, okullarda olumlu bir işbirliği ortamının sağlanması gerektiği önerisinde bulundukların belirlemiştir. Araştırma bulguları Gökçe'nin (2000) araştırma bulgularını desteklemektedir. Özel eğitim öğretmenleri ise kendi aralarında fikir alış verişi ve öğrenciler için neler yapılabileceği konusunda işbirliği yapılan önemli unsurlardır. Araştırmaya katılan öğretmenlerin tamamı işbirliğinin kesinlikle önemli olduğunu belirtmişlerdir. İşbirliği özellikle özel eğitimin temel parçalarından biri olduğu ve öğrencilerin akademik ve sosyal olarak ilerlemelerini kolaylaştıracağı kaçınılmaz bir gerçektir. Bunun yanında işbirliğinin problem davranışlara müdahalede etkili bir yol olduğunu belirtilmiştir (Özgan ve Aydın, 2010). Öğretmenler ailelerle işbirliği konusunda eğitim seviyesi, gelir düzeyi ve cinsiyetin çok önemli olduğunu belirtmişlerdir. Özel eğitim öğretmenleri kendilerini daha iyi ifade ettikleri için genellikle öğrencilerin anneleri ile işbirliği yaptıklarını ifade etmişleridir. Çalışmamıza katılan öğretmenler bu değişkenlerin ailelerle işbirliğini etkilediğini savunmuşlardır. Arslanargun (2007)' tarafından 
oluşturulan çalışmada ailelerle işbirliğinin geliştirilmesinde yukarıda belirtilen değişkenlerin etkili olduğu vurgulamıştır.

Alan yazın incelendiğinde özel eğitim öğretmenlerinin problem davranışlara müdahalede işbirliğinin önemine yönelik kısıtlı sayıda çalışmanın olması araştırmanın sınırlılığıdır. Çalışma ile işbirliği konusunda öğretmenler desteklenmeli, okuldaki problem davranışara okul idaresi önlemler almaya çalışmalı, işbirliğinin oluşması için aile öğretmen sürekli etkileşim içerisinde olmalıdır. Öğretmenler problem davranışlarla başa çıkmaları konusunda bilgilendirmeler yapılmalı, rehberlik servisleri daha çok sürece hâkim olmalı, okulda yapılan eğitimler evde de devam ettirilmesi konusunda aile işbirliğinin sağlanması konusunda öneriler sunulabilir. 


\title{
EXTENDED ABSTRACT
}

\section{The Importance of Private Education Teachers For The Importance and Implementation of Cooperation in The Problem Behavior Intervention}

\author{
Burhannettin Karakoç - Zehra Atbaşı \\ Ministry of National Education, Nercmettin Erbakan University
}

The main purpose of education is to ensure a healthy and productive adaptation of all individuals to society, to discover students' abilities by eliminating problem behaviors occurring in the school, and to bring up effective and efficient individuals. The knowledge, skills, habits and values gained at school significantly affect not only the educatonal life of the child, but also his communication and life skills towards himself, society and the world outside himself (Sadık, 2000; Senemoğlu, 1992).

There are many problem behaviors experienced in schools. While these problem behaviors prevent students from learning, they affect the classroom environment negatively and cause negative effects for teachers and other students (Özbey, 2010).

As a result of this situation, students who exhibit a certain level of problem behaviour cannot benefit from education and training opportunities sufficiently and may turn into a risk factor for academic and other fields (Chandler and Dahlquist, 2002; Kırcaal1-İftar and Tekin İftar, 2004; Putman, Luiselli, Handler and Jefferson, 2003). Therefore, problem behaviors should be reduced or eliminated in order to increase the performance of students in school and to make the school environment more suitable for everyone (Chandler and Dahlquist, 2002; Erbaş, 2008).

Collaboration is a way to encourage teachers to support each other. Moreover, collaboration between teachers is seen as a critical component necessary to help meet the needs of students with special needs (Friend and Cook, 2012). However, teachers' beliefs and value judgments affect the collaboration process (Bhandari, 2013). Collaboration for teachers can improve learning and teaching (Goddard and Heron, 2001) and present positive results such as increasing effectiveness (Shachar and Shmuele- 
vitz, 1997), developing a positive attitude towards teaching (Yeager, Rennells and Riley, 1997) and maintaning a high level of trust (Tschannen-Moran , 2001). School management should provide the necessary environment and support in order to enhance this communication. Elimination of problem behaviors observed in special education students involves a more difficult and longer process than students with normal development (Özgan and Aydın, 2010). When the relevant literature is examined, it is seen that the importance of cooperation in special education is emphasized (Batu and Kırcaali-İftar, 2006; Sucuoğlu and Kargın, 2014). However, such studies mainly emphasized parent-teacher cooperation rather than direct cooperation (Sivrikaya and Yıkmış, 2017). Özsoy (2019) concluded in her study that special education teachers primarily prefer to cooperate with other teachers and their level of cooperation with families is at the lowest level, and that special education teachers generally cooperate with school principals, other teachers and families.

The communication of the school and the teachers with the family can be effective in decreasing the negative behaviors of the students while increasing the academic success and interest in school in children and young people. With the increase in students 'desire to work, an internal control mechanism is formed in students. As a result of the increase in the internal control mechanism, students' self-identity is formed in a positive way (Ceylan and Akar, 2010).

Considering the problem behaviors and their effects, the intervention are emphasized with a holistic approach. However, there are no descriptive or experimental studies on the importance of cooperation in treating problem behaviors within a holistic perspective. Therefore, the aim of the study is to determine the opinions of special education teachers about the importance and implementation of cooperation in intervention in problem behaviors.

Qualitative research approach was used in this study. This approach has been taken as the basis since it is considered to be the most appropriate approach in determining the ideas and experiences of special education teachers fulfilling line with the determined purpose. The study group consist of 15 special education teachers working in special education schools in te center of Sivas. In this study, the interview method was chosen to determine the importance of cooperation in intervention to 
problem behaviors of special education teachers and their views on its implementation, and a semi-structured interview form was created for this purpose. At the next stage, the opinion of an expert who is a lecturer in the special education department and who has studies on these issues was taken, and a pilot study was conducted with a special education teacher with similar characteristics to the participant group of the study. The interview form was finalized after the necessary arrangements were made. Data in the study were obtained through semi-structured interview form.

Since the sample group of the study consists of special education teachers affiliated to the Ministry of National Education in Sivas Province, research permission has been obtained primarily from the Provincial Directorate of National Education. As a result of the approval of the Provincial Directorate of National Education to carry out the relevant research, the schools included in the annex of the research permit petition were visited with a letter of permission. The details of the relevant work were presented to the special education teachers in these schools, and meetings were held with the volunteer teachers in the fall semester of 2019.

The interview protocol developed during the interviews was applied. This protocol includes items on the effective use of interviewer techniques such as asking questions to all participants in the same way, expanding, repeating and summarizing the answers given to the questions by the researcher conducting the interview. The interviews were conducted with a tape recorder after permission was obtained for the audio recording, and then the recordings were transcribed.

After the interviews were made during the research process, the answers given by the participants were transferred to the computer environment. The interview transcript was read one by one by the two researchers before coding the views obtained. Descriptive analysis technique was used in the analysis of the interview data. As a result of the research, all of the teachers stated that they encountered many problem behaviors in school, the most common problem behaviors are students harm themselves, hurt their friends, constantly walking around, yelling, having tantrums, eating wet wipes and foreign materials they find, eating disorder (pouring food. They stated that they encountered problem 
behaviors such as throwing plates, and toileting to the activity areas. Most of the teachers stated that they cooperated with parents and special education teachers, and then they cooperated with the school administration, guidance service and rehabilitation center. A small number of participants stated that they communicated with other teacher friends and branch teachers in the classroom. All of the teachers who participated in the study stated that cooperation is absolutely important. Special education teachers stated that students generally cooperate with their mothers because they express themselves better. The teachers who participated in our study argued that these variables affect cooperation with families.

\section{Kaynakça / References}

Alberto, P.A. ve Troutman, A.C. (2012). Applied behavior analysis for teachers (9th Edition). Boston, MA: Pearson

Akbaşlı, S. ve Kavak, Y. (2008). Ortaöğretim okullarındaki okul aile birliklerinin görevlerini gerçekleştirme düzeyi. Selçuk Üniversitesi, Sosyal Bilimler Enstitüsü Dergisi. 1(19). 1-21.

Anlıak,Ş., ve Dinçer, Ç. (2005). Farklı eğitim yaklaşımları uygulayan okul öncesi eğitim kurumlarına devam eden çocukların kişiler arası problem çözme becerilerinin değerlendirilmesi. Ankara University, Journal of Faculty of Educational Sciences, 38(1), 149-166

Aslanargun, E. (2007). Okul- aile işbirliği ve öğrenci başarısı üzerine bir tarama çalışması. Sosyal Bilimler Dergisi. 9(18). 119-135

Atbaşı, Z, karasu, N. Ve Tavil. Y. (2018). Sınıf Genelinde Olumlu Davranış Desteği Program: Check-In/Check-Out Uygulaması. Eğitim ve Bilim Dergisi.

Atc1, A. (2004). Illköğretim 1. kademe öğretmenlerinin sinnf içi problem davranışlara yönelik müdahalelerinin incelenmesi. Yayımlanmamış Yüksek Lisans Tezi, Çukurova Üniversitesi Sosyal Bilimler Enstitüsü, Adana.

Balkar, B. (2009). Okul- aile işbirliği sürecine ilişkin veli ve öğretmen görüşleri üzerine nitel bir çalışma. Çukurova Üniversitesi Eğitim Fakültesi Dergisi, 36(3), 105123

Cavkaytar, A. (2018). Özel eğitim. Ankara. Vize akademi yayınclık.

Chandler, L. K. ve Dahlquist, C. M. (2002). Functional assessment: strategies to prevent and remediate challenging behaviors in school settings. Columbus Ohio: Merill, Prentice Hall. 
Ceylan, M. Ve Akar, B. (2010). Ortaöğretimde okul- aile işbirliği ile ilgili öğretmen ve veli görüşlerinin incelenmesi. Çankır Karatekin Üniversitesi Sosyal Bilimler Enstitüsü Dergisi, 2, 43-64.

Cook, L., ve Friend, M. (1991). Principles for the practice of collaboration in schools. Preventing School Failure, 35(4), 6-9.

Emerson, E. (2001). Challenging behaviour: Analysis and intervention in people with severe intellectual disabilities. Cambridge University Press, 2001.

Erbaş, D. (2002). Problem davranışların azaltılmasında olumlu davranışsal destek planı hazırlama. Özel Ë̆gitim Dergisi, 3(2), 41-50.

Erbaş, D. (2008). Özel eğitim öğretmenleri tarafından uygulanan olumlu davranışsal destek programının etkililiği. Ankara Üniversitesi Ĕ̆itim Bilimleri Fakültesi. Özel Eğitim Dergisi. 2008, 9 (2) 1-14

Ekiz, D. (2013). Bilimsel araştırma yöntemleri. Ankara: Anı yayıncılık.

Friend, M., ve Cook, L. (2000). Interactions: Collaboration skills for school professionals (7th. ed.). Boston, MA: Pearson.

Goddard, Y. L., Goddard, R. D., ve Tschannen-Moran, M. (2007). Theoretical and empirical investigation of teacher collaboration for school improvement and student achievement in public elementary schools. Teachers College Record, 109(4), 877-896.

Çelenk, S. (2003). Okul başarısının ön koşulu: Okul aile dayanışması. ilköğretimOnline, e-dergi, 2(2), 28-34,

Gümüseli, A.İ. (2004). Ailenin katılım ve desteginin ögrenci basarısına etkisi. Özel Okullar Birligi Bülteni. 2(6), 14-17. 10 Mart 2020 tarihinde www.agumuseli.com/ dokumanlar/ makale/ ailekatilimiögrencibasarisi.pdf adresinden erişilmiştir.

Gökçe, E. (2000). İköğretimde okul aile işbirliğinin geliştirilmesi. Pamukkale Üniversitesi Ĕ̈itim Fakültesi Dergisi, 7.

Goddard, Y. L., ve Heron, T. E. (2001). The consultation process. T. E. Heron ve K. C. Harris, The educational consultant: Helping professionals, parents, and mainstreamed students içinde (4th ed., s. 3-37). Austin, TX: PRO-ED.

Karasar, N. (2006). Bilimsel araştırma yöntemi. Ankara: Nobel Yayın Dağitım.

Kapucuoğlu-Tolunay, A. (2008). Sınıf öğretmenlerinin sınıfta karşılaştıkları istenmeyen öğrenci davranışları ve bu davranışlara karşı kullandıkları Ĕgitim $F a-$ kültesi Dergisi 30 (1), 239-264 
Keskin, R. (2009). Sinıf öğretmenlerinin simf yönetimi ve istenmeyen öğrenci davranışlarıla baş etmede kullandiklan yöntemlere ilişkin görüşlerinin belirlenmesi. Yayımlanmamış Yüksek Lisans Tezi, Yeditepe Üniversitesi Sosyal Bilimler Enstitüsü, İstanbul.

McHenry, A. N. (2009). The relationship between leadership behaviors, teacher collaboration, and student achievement. Doctoral Dissertation, The University of Southern Mississippi, Mississippi.

Özgan, H., ve Aydın, Z. (2010). Okul-aile işbirliğine ilişkin yönetici, öğretmen ve veli görüşleri. e-Journal of New World Sciences Academy Education Sciences, 5(30), 1169-1189.

Radić-Šestić, M., Radovanović, V., Milanović-Dobrota, B., ve Slavkovic, S. (2013). General and special education teachers' relations within teamwork in inclusive education: Socio-demographic characteristics, South African Journal of Education 33(3), 1-15.

Roustaee, R., Pourrajab, M., Kasmaienezhadfard,S., ve Taleblo, B. (2015). The relationship between demographic variables and collaborative learning activities of teachers, International Journal Of Scientific \& Technology Research 4(6), 430434.

Özbey, S. (2010). Okul öncesi çocuklarda uyum ve davranış problemleriyle başa çlkmada ailenin rolü. Aile ve Toplum Araștrma Dergisi. 11(6).ISSN: 13030256.

Özsoy, B. (2019). Özel eğitim öğretmenlerinin müdürlerle, diğer öğretmenlerle ve ailelerle olan işbirliği düzeylerinin belirlenmesi. Yüksek Lisans Tezi. Gazi Eğitim Bilimleri Enstitüsü.

Yıldırım, A, ve Şimşek, H. (2006). Sosyal bilimlerde nitel araştırma yöntemleri. Ankara: Seçkin

Sadık, F. (2000). İlköğretim I. aşama sinıf öğretmenlerinin sinıfta gözlemledikleri problem davramışlar. Ç.Ü. Eğitim Fakültesi. Eğitim Bilimleri ABD.

Sazak-Pınar, E. ve Güner-Yıldız, N. (2013). Genel eğitim sınıflarındaki özel gereksinimli öğrencilerin sergilediği problem davranışların ve bu davranışlara yönelik gösterilen öğretmen tepkilerinin incelenmesi. 23. Ulusal Özel Eğitim Kongresi'nde sunulan bildiri (30 Ekim-1Kasım, Bolu), Ankara: Pegem A Yayinclik. 63-64.

Senemoğlu, N. (1992). İngiltere'de ilköğretime öğretmen yetiştirme ve Türkiye ile karşılaştırlması. Türkiye'de İlköğretim Sempozyumu, 21-22 Mayıs 1992, Ankara: Hacettepe Üniversitesi Eğitim Fakültesi Yayınları, 8. 
Sivrikaya, T. Ve Yıkmış, A. (2017). Özel Eğitim Sınıflarında Görev Yapan Özel Eğitim Mezunu Olan Ve Olmayan Öğretmenlerin Öğretim Süreciyle İlgili Gereksinimler. Abant İzzet Baysal Üniversitesi Eğitim Fakültesi Dergisi. 16(4).

Sharon S., Carol. C., Thomas, R., Robert, O., ve Caterina, V. (1997). Meeting the Challenge of Consultation and Collaboration: Developing Interactive Teams. 30(4), 427-432. https://doi.org/10.1177/002221949703000409.

Sönmez, V. ve Alacapınar, G. F. (2011). Örneklendirilmiş bilimsel araştırma yöntemleri. Ankara: Anı yayıncilı.

Shachar, H., ve Shmuelevitz, H. (1997). Implementing cooperative learning, teacher collaboration and teachers' sense of efficacy in heterogeneous junior high schools, Contemporary Educational Psychology, 22, 53-72.

Sugai, G., ve Horner, R. (2002). The evolution of discipline practices: School-wide positive behavior supports. Child \& Family Behavior Therapy, 24(1-2), 23-50.

Thousand, J., Nevin, A., McNeil, M., ve Liston, A. (2006, Nov.) Differentiating instruction in inclusive classrooms: Myth or reality? Paper Presented at TED/TAM, San Diego.

Tschannen-Moran, M. (2001). Collaboration and the need for trust. Journal of Educational Administration, 39, 308-331

Walther-Thomas C. (1997). Co-teaching experiences: the benefits and problems that teachers and principals report over time. Journal of Learning Disabilities, 30(4), 395-399.

\section{Kaynakça Bilgisi / Citation Information}

Karakoç, B. ve Atbaşı, Z. (2020). Özel eğitim öğretmenlerinin problem davranışlaramüdahalede işbirliğinin önemine ve uygulanmasına yönelik görüşleri. OPUS-Uluslararası Toplum Araştırmaları Dergisi, 16(29), 1666-1688. DOI: 10.26466/opus.727238 